DOI: http://doi.org/10,21009/JKKP.082.08

\title{
KONSEP DIRI SEBAGAI PENGONTROL IMPULSE BUYING PADA IBU RUMAH TANGGA
}

\author{
Aliya Syalikha Desriane ${ }^{\left.1^{*}\right)}$, Hamiyati $^{1}$, Elmanora ${ }^{1}$ \\ ${ }^{1}$ Program Studi Pendidikan Kesejahteraan Keluarga, Fakultas Teknik, Universitas Negeri Jakarta, \\ Jakarta Timur 13220, Indonesia \\ ${ }^{*}$ E-mail: aliya25likha@gmail.com
}

\begin{abstract}
Abstrak
Penelitian ini bertujuan untuk menganalisis pengaruh konsep diri terhadap impulse buying pada ibu rumah tangga. Penelitian ini dilakukan di Kelurahan Baros, Kota Sukabumi, Provinsi Jawa Barat. Penelitian ini melibatkan 100 orang ibu rumah tangga yang dipilih secara puposive. Pengumpulan data dilakukan pada bulan April sampai dengan Juni 2021 dengan menggunakan metode survey. Data dianalisis dengan menggunakan statistika deskriptif dan statistika inferensial (uji regresi linear sederhana). Hasil penelitian menunjukkan bahwa konsep diri dan impulse buying pada ibu rumah tangga termasuk dalam kategori sedang. Konsep diri berpengaruh negatif dan signifikan terhadap impulse buying. Hasil analisis ini mengindikasikan bahwa konsep diri yang semakin baik dapat menurunkan impulse buying pada ibu rumah tangga. Artinya, impulse buying pada ibu rumah tangga dapat dikontrol oleh konsep diri ibu rumah tangga tersebut. Dengan demikian, cara yang dapat dilakukan untuk mengurangi impulse buying pada ibu rumah tangga adalah dengan cara meningkatkan konsep diri pada ibu rumah tangga.
\end{abstract}

Kata kunci: ibu rumah tangga, impulse buying, konsep diri, perilaku konsumen

\section{Self-Concept as Impulse Buying Controller in Homemakers}

\section{Abstract}

This study aims to analyze the effect of self-concept on impulse buying at homemakers. The location conducted this research is Baros Village, Sukabumi City, West Java Province. This study involved 100 homemakers who were selected purposively. Data collection was carried out from April to June 2021 using the survey method. Data were analyzed using descriptive statistics and inferential statistics (simple linear regression test). The results showed that homemakers had self-concept and impulse buying in the medium category. Self-concept has a negative and significant effect on impulse buying. The results of this analysis indicate that a better self-concept can reduce impulse buying for homemakers. That is, the housewife's self-concept can control impulse buying at homemakers. Thus, the way to minimize impulse buying for homemakers is by increasing the self-concept of homemakers.

Keywords: consumer behavior, homemakers, impulse buying, self-concept

\section{PENDAHULUAN}

Perkembangan era globalisasi di Indonesia sudah mengalami perubahan khususnya pada teknologi. Teknologi yang canggih dan modern menghasilkan kemajuan bagi manusia untuk mengakses internet. Kemudahan tersebut memberikan manfaat positif yang sudah menjadi kebutuhan manusia, karena internet telah diakui dan dirasakan dalam hal menjalani aktivitas untuk bepergian, berbelanja dan memenuhi kebutuhan rumah tangga. Sehingga setiap manusia yang memiliki kebutuhan perlu mencari cara untuk terpenuhinya kebutuhan tersebut. Ada banyak cara yang dapat dilakukan untuk memenuhi kebutuhan, salah satunya adalah dengan cara membeli. Berbagai macam bentuk produk yang ditawarkan di pasaran diperuntukan agar memudahkan para konsumen untuk dapat memuaskan atau memenuhi kebutuhan mereka. Tingginya pengguna internet di Indonesia menjadi salah satu faktor penyebab munculnya toko-toko online di Indonesia (Ramadhan \& Simanjuntak, 2018). 
Berbelanja secara online memang saat ini sedang dinikmati oleh sebagian besar masyarakat, karena dengan cara baru inilah masyarakat tidak perlu merasa kesulitan lagi untuk memperoleh barang yang diinginkan (Sari et al., 2018). Awal mulanya, konsumen akan membeli sebuah produk dengan menggunakan uang tunai. Hingga saat ini sistem pembayaran tunai masih diminati oleh masyarakat. Kemudahan dalam pembelian dan pembayaran produk melalui sistem transaksi pembelian barang dagang atau lainnya secara tunai juga dapat dilakukan dengan cara pembelian non-tunai.

Akibat terjadinya Covid-19 banyak masyarakat yang melakukan belanja online dan menggunakan transaksi non-tunai untuk mencegah terjadinya penyebaran Covid-19 ini. Pasalnya, Covid-19 telah mengganggu mata rantai produksi industri sehingga perputaran bisnis menjadi tidak lancar, sementara kewajiban para pengusaha tetap harus berjalan. Metode transaksi non-tunai yang kini cukup populer di Indonesia, sehingga masyarakat lebih mudah dan praktis dalam menjalani aktivitas sehari-hari. Beragam cara pembayaran non- tunai kini mulai bermunculan diperekonomian Indonesia untuk mendukung pertumbuhan masyarakat, dengan banyaknya promo yang diberikan oleh perusahaan. Selain itu, banyak manfaat yang diberikan dalam bentuk promosi untuk para penggunanya. Menurut Oktivera et al., (2020) tawaran ini semakin mendorong konsumen untuk semakin melakukan transaksi pembayaran dengan menggunakan digital payment dan melakukan pembelian seketika (impulse buying). Inilah yang menyebabkan banyak masyarakat tertartik untuk mencoba dan menggunakannya, tetapi disisi lain banyaknya promosi yang diberikan menimbulkan kecenderungan perilaku konsumtif penggunanya (Maula \& Kustanti, 2020). Tetapi di sisi lain, konsumen menjadi tidak sadar kalau mereka menjadi semakin konsumtif karena merasa tidak terlalu berat mengeluarkan sejumlah uang berjumlah agak besar dalam bentuk dana digital dibandingkan jika mereka melakukan pembayaran dengan jumlah yang sama secara tunai (Kusnawan et al., 2019).

Bressolles dkk. (2007) menyoroti pentingnya faktor terkait situs web dalam pembelian impulsif dengan mengusulkan model pembelian impulsif yang dipengaruhi oleh kualitas situs web yang dimediasi oleh kepuasan pelanggan. Parboteeah et al. (2009) mengemukakan bahwa tugas berkualitas tinggi yang relevan dan isyarat relevan suasana hati secara signifikan mempengaruhi kemungkinan pembelian impulsif online. Kecanduan internet dan hubungannya yang signifikan dengan pembelian impulsif online juga diperiksa dengan prediktor sifat pembelian impulsif online lainnya Sun dan Wu, diacu dalam Shingh, 2019). Keputusan konsumsi rumah tangga juga dapat memengaruhi keseluruhan perilaku perekonomian, baik dalam jangka panjang maupun jangka pendek. Kontribusi konsumsi yang besar tentu akan sangat berpengaruh terhadap perekonomian suatu negara jika terjadi perubahan terhadap konsumsi masyarakat (Ramadhani et al., 2019).

Peran ibu rumah tangga dalam mengurus kebutuhan-kebutuhan tersebut tidaklah mudah, karena setiap individu mempunyai kebutuhan masing-masing dan di dalam kehidupan sehari-hari tidak akan lepas dari kegiatan konsumsi. Peran utama perempuan adalah sebagai ibu rumah tangga yang harus memberikan tenaga dan perhatiannya demi kepentingan keluarga tanpa boleh mengharapkan imbalan, prestise serta kekuasaan. Ibu berperan dominan dalam kehidupan suatu keluarga, ibu mempunyai kewajiban membantu suami dalam mempertahankan rumah tangga, mengatur segala keperluan rumah tangga, merawat serta memperhatikan pendidikan anak, mengatur keuangan sehingga terjadi keselaran antara pendapatan dan kebutuhan rumah tangga sehingga terjadi suatu kondisi yang dapat dikatakan menjapai kesejahteraan dalam sebuah keluarga. Apabila perilaku konsumtif terus menerus terjadi maka akan mengakibatkan kondisi keuangan menjadi tidak terkontrol selain itu akan menimbulkan tindakan pemborosan dan berakibat pada menumpuknya barang karena pembelian yang dilakukan secara berlebihan atau terus menerus. Apabila hal tersebut terus menerus dilakukan para ibu maka akan mengakibatkan tindakan pemborosan, dan mengakibatkan tidak terkontrolnya keuangan keluarga. Smith dkk, diacu dalam Oke et al., 2016) menekankan bahwa kepribadian seseorang dianggap sebagai konsep diri dan persepsi diri yang memengaruhi pilihannya untuk membeli suatu barang. Menurut Sari et al. (2018), 
saat ini tidak hanya kalangan remaja saja yang aktif dalam berbelanja online pada jejaring sosial tetapi ibu rumah tangga pun kini juga menggunakan online shop pada jejaring sosial untuk memenuhi kebutuhan sehariharinya. Konsep diri positif bukanlah kebanggaan besar tentang diri tetapi lebih berupa penerimaan diri. Menurut Nurhaini (2018) seseorang yang mempunyai konsep diri positif akan menjadi individu yang mampu memandang dirinya secara positif, berani mencoba dan mengambil resiko, selalu optimis, dan percaya diri. Konsep diri merupakan sesuatu yang dimiliki oleh seseorang yang dapat mengontrol perilaku dirinya sendiri. Konsep diri dijadikan salah satu faktor pembeda antar konsumen. Tetapi, konsep diri yang dimiliki seseorang tentunya memiliki perbedaan antara satu sama lain (Ramadhan \& Simanjuntak, 2018). Konsep diri dipelajari melalui pengalaman dan interaksi individu dengan orang lain, berkembang secara bertahap (Pramesty \& Simanjuntak, 2020). Seseorang perlu memiliki konsep diri, karena berpengaruh sangat penting bagi manusia terutama sebagai konsumen, oleh karenanya manusia perlu memiliki konsep terhadap dirinya agar dapat menentukan pilihan yang sejalan dengan keinginan seseorang. Jika seseorang tersebut mengenal dirinya dengan baik, maka tidak akan terpengaruh sebaliknya jika seseorang tidak memiliki konsep diri maka dapat berubah bila seseorang tersebut tidak berusaha. Maka dari penjelasan di atas penelitian ini bertujuan mengetahui Pengaruh Konsep Diri Terhadap Impulse Buying pada Ibu Rumah Tangga.

\section{METODE}

Metode penelitian yang digunakan adalah metode penelitian asosiatif dengan pendekatan kuantitatif. Populasi dalam penelitian melibatkan 100 orang ibu rumah tangga di Kelurahan Baros, Kota Sukabumi, Provinsi Jawa Barat yang dipilih secara puposive sampling. Waktu pengambilan data selama 3 bulan terhitung dilaksanakan pada bulan April hingga Juni 2021. Metode yang digunakan dalam pengumpulan data adalah menggunakan teknik pengumpulan data penyebaran angket (kuesioner) secara langsung.

Pembelian impulsif merupakan perilaku ibu rumah tangga yang ditandai dengan adanya pembelian secara spontan yang dapat menghasilkan keputusan yang cepat dalam memutuskan sesuatu tanpa pertimbangan yang matang serta cenderung berulang dan tindakan tersebut dianggap wajar. Instrumen dikembangkan dari penelitian Uygur (2018), yang terdiri atas tiga dimensi, tiga indikator, dan sembilan butir pernyataan. Instrumen ini menggunakan skala Likert, dengan pengukuran mulai dari (1) Sangat tidak setuju, (2) Tidak setuju, (3) Netral, (4) Setuju, dan (5) Sangat setuju, dan kebalikannya jika butir negatif. Skor yang diperoleh pada variabel pembelian impulsive dijumlahkan dan dikonversikan dalam bentuk indeks. Setelah itu, data dikategorikan menjadi tiga kategori yaitu: rendah (indeks $<60$ ), sedang (indeks 60-80), dan tinggi (indeks $>80$ ). Instrumen butir pertanyaan telah valid dan reliabel dengan Cronbach's alpha sebesar 0,823.

Konsep diri adalah gambaran atas sikap dan perasaan ibu rumah tangga tentang dirinya yang dipelajari melalui pengalaman pribadi maupun yang berhubungan dengan orang lain yang dapat memengaruhi perilaku dirinya sendiri. Instrumen dikembangkan dari penelitian Toth (2014) yang terdiri atas empat dimensi, empat indikator, dan 54 butir pernyataan. Instrumen ini menggunakan skala Likert, dengan pengukuran yaitu mulai dari, (1) Sangat tidak setuju (2) Tidak setuju, (3) Netral, (4) Setuju (5) Sangat setuju, dan kebalikannya jika butir negatif. Instrumen butir pernyataan untuk variabel konsep diri telah valid dan reliabel dengan Cronbach's alpha sebesar 0,944.

Analisis data yang digunakan dalam penelitian ini adalah analisis deskriptif dan uji regresi linear sederhana. Analisis deskriptif untuk menghitung jumlah dan persentase dari kategori, nilai rata-rata, dan standar deviasi dari setiap variabel penelitian. Selanjutnya, uji regresi linear sederhana digunakan untuk menganalisis pengaruh konsep diri terhadap impulse buying pada ibu rumah tangga. 
Desriane, Hamiyati, \& Elmanora, JKKP 8 (02) (2021) 199-209

\section{HASIL DAN PEMBAHASAN}

\section{Karakteristik Responden}

Responden yang terlibat dalam penelitian ini berusia 21-40 tahun (30\%) dan 41-65 sebesar (70\%). Menurut Papalia, Sterns, Feldman, dan Camp (2007), diacu dalam (Sari et al., 2018) tingkatan usia dibagi menjadi 2 yaitu dewasa muda 20-40 tahun dan dewasa menengah 41-65 tahun. Dengan demikian sebagian besar responden dalam penelitian ini termasuk kategori dewasa madya. Sebagian responden dalam penelitian ini telah menyelesaikan pendidikan pada jenjang SMA/Sederajat berjumlah (50\%). Berdasarkan data tersebut dapat diketahui bahwa semakin tinggi tingkat pendidikan seseorang, maka semakin mudah seseorang untuk menerima informasi, sehingga semakin banyak pula pengetahuan yang dimiliki, begitu pula jika tingkat pendidikan rendah.

\section{Impulse Buying}

Dimensi pertama dari impulse buying adalah hedonik. Dimensi ini mengukur perasaan seseorang yang tidak pernah puas berdasarkan yang dirasakan dalam menyenangkan diri sendiri. Dimensi hedonic terdiri atas empat pernyataan. Pernyataan pertama, sebanyak 33\% responden menjawab setuju, hal ini dapat diartikan bahwa motivasi hedonis dari konsumen merupakan salah satu aspek terpenting untuk membentuk perilaku yang impulsif. Saat konsumen sudah memiliki rasa senang dan gembira saat hendak membeli sebuah produk, maka pembelian impulsif dapat timbul secara sendirinya (Astiti \& Puri, 2016). Pertanyaan kedua, sebanyak $50 \%$ responden menjawab setuju, hal ini menjelaskan bahwa keinginan untuk membeli secara tiba-tiba dapat menyebabkan konsumen berada dalam kondisi ketidakseimbangan psikologis yaitu kondisi sementara dimana konsumen kehilangan kontrol emosinya. Konsumen yang mungkin mengalami konflik psikologis akan berjuang mempertimbangkan kepuasan, kegembiraan dan kesenangan dirinya (Aprilia \& Mahfudzi, 2020). Pertanyaan ketiga, sebanyak 35\% menjawab netral, hal ini dikarenakan konsumen merasa berada di tengah-tengah perilaku tersebut. Hal ini sesuai dengan penelitian (Aprilia \& Mahfudzi, 2020) yang menyatakan bahwa individu dengan impulse buying yang rendah mampu mengatur dan mengendalikan dirinya terhadap pengaruh lingkungan begitupun sebaliknya. Pertanyaan keempat, sebanyak $46 \%$ menjawab netral dan $46 \%$ menjawab setuju, hal ini menjelaskan bahwa pembelian produk tergantung pada faktor internal yaitu faktor yang berasal dari dalam diri individu, yang meliputi mudah terpengaruh dan emosi yang negatif (Aprilia \& Mahfudzi, 2020). Secara umum, impulse buying pada ibu rumah tangga, khususnya dimensi hedonik termasuk kategori sedang.

Dimensi kedua dari impulse buying adalah kognitif. Dimensi ini mengukur suatu pemikiran seseorang dalam mengambil keputusan. Hasil penelitian menunjukan bahwa responden membeli suatu produk yang belum tentu memiliki fungsi. Hal ini ditandai dengan sebanyak $30 \%$ responden menjawab setuju sehingga dapat disimpulkan bahwa faktor pengalaman berpengaruh terhadap perilaku konsumtif berupa pemborosan, pembelian secara impulsif, dan pembelian secara tidak rasional (Chrisnawati \& Abdullah, 2011). Hasil menunjukkan bahwa secara keseluruhan dimensi komponen kognitif berada pada kategori sedang dengan nilai rata-rata 67,0. Artinya dimensi komponen kognitif pada responden memiliki pengambilan keputusan pembelian yang kurang tepat karena tidak dipikirkan dan tidak diketahui fungsinya dalam membeli suatu produk.

Dimensi terakhir dari impulse buying adalah perencanaan. Dimensi ini mengukur spontanitas atau kesegeraan dalam membuat keputusan dalam situasi pembelian tertentu. Pada pernyataan pertama dimensi perencanaan, sebanyak $32 \%$ menjawab netral hal ini menunjukkan bahwa masih banyak konsumen yang seringkali melakukan pembelian melebihi dari rencana pembelian sebelumnya. Pertanyaan kedua, sebanyak $31 \%$ menjawab setuju hal ini sesuai dengan penelitian (Muflih, 2018) bahwa perilaku pembelian semakin komplek, yang mana seringkali konsumen membeli produk tidak dalam rutinitas melainkan sebagai pembelian berdasarkan situasi yang diinginkan. Keinginan membeli suatu produk bisa datang 
tiba-tiba karena berbagai alasan situasional. Pertanyaan ketiga, sebanyak 39\% menjawab netral hal ini karena tergantung pada perilaku konsumen terhadap rencana sebelum melakukan pembelian suatu produk. Konsumen biasanya akan merencanakan terlebih dahulu tentang produk yang akan dibelinya, jumlah anggaran, tempat pembelian, dan kebutuhan umum yang belum ditetapkan (Muflih, 2018). Pertanyaan keempat, sebanyak $30 \%$ menjawab setuju, hal ini dapat disebabkan oleh besarnya pengaruh stimulus di dalam toko yang mampu membangkitkan gairah konsumen saat memasuki sebuah toko sehingga pada akhirnya dapat melakukan tindakan pembelian (Astiti \& Puri, 2016). secara keseluruhan dimensi komponen perencanaan berada pada kategori sedang dengan nilai rata-rata 63,5 . Artinya dimensi komponen perencanaan pada responden sering kali membeli suatu produk yang melebihi dari rencana dan sesuai dengan keinginan.

Impulse buying pada ibu rumah tangga dalam penelitian ini mempunyai nilai rata-rata 65,5 (Tabel 1). Pada dimensi komponen hedonik berada pada kategori sedang dengan nilai rata-rata 68,0 . Artinya pada responden kurang mengendalikan pikiran dan dirinya dengan baik terhadap suatu dan dapat mudah terpengaruh oleh lingkungan. Pada dimensi komponen kognitif berada pada kategori sedang dengan nilai rata-rata 63,5. Artinya pada responden membeli suatu produk yang belum tentu diketahui fungsinya. Pada dimensi perencanaan berada pada kategori sedang dengan nilai rata-rata 63,5. Artinya perencanaan pada responden sering kali membeli suatu produk yang melebihi dari rencana dan sesuai dengan keinginan.

Tabel 1 Dimensi Variabel Impulse Buying

\begin{tabular}{lccr}
\hline \multicolumn{1}{c}{ Dimensi } & Nilai Min-Mak & $\begin{array}{c}\text { Rata-rata } \pm \text { Standar } \\
\text { Deviasi }\end{array}$ & Kategori \\
\hline Hedonik & $45-95$ & $68,0 \pm 11,9$ & Sedang \\
Kognitif & $20-100$ & $67,0 \pm 23,7$ & Sedang \\
Perencanaan & $30-100$ & $63,5 \pm 17,1$ & Sedang \\
\hline Impulse Buying & $35-95$ & $65,8 \pm 13,4$ & Sedang \\
\hline
\end{tabular}

\section{Konsep Diri}

Dimensi pertama dari konsep diri adalah actual self concept. Dimensi ini mengukur bagaimana seseorang sebenarnya melihat dirinya sendiri. Konsep ini menjelaskan bagaimana konsumen memandang dirinya akan memengaruhi produk yang dibeli dan digunakannya. Pada dimensi actual self concept pada kategori menjawab tidak setuju sebanyak $42 \%$ pada pernyataan saya orang yang mudah bingung ketika berhadapan dengan beberapa pilihan dan pada pernyataan saya orang yang ceroboh dan sebanyak $41 \%$ pada pernyataan saya orang yang keras kepala selalu ingin lebih. Hal ini dikarenakan konsep diri sangat erat kaitannya dengan diri individu. Kehidupan yang sehat, baik fisik maupun psikologi salah satunya didukung oleh konsep diri yang baik dan stabil (Anissa dan Handayani, 2012). Selanjutnya menurut Hurlock, diacu dalam Gamayanti (2016) dalam penyesuaian diri serta mampu mengenali kelebihan dan kekurangannya, memiliki keyakinan diri (self confidence) dan harga diri (self esteem), lebih bisa menerima kritik, penerimaan diri yang disertai dengan rasa aman memungkinkan seseorang untuk menilai dirinya secara lebih realistis sehingga dapat menggunakan potensinya secara efektif.

Diri secara keseluruhan yang dialami oleh individu, sering disebut 'diri-fenomenal'. Diri fenomenal ini adalah diri yang diamati, dialami dan dinilai oleh individu itu sendiri; inilah diri yang disadari. Jumlah keseluruhan dari semua kesadaran ini atau persepsi-persepsi tentang citra dirinyaitulah konsep dirinya (Widiarti, 2017). Konsep diri terbentuk dari beberapa hal, menurut Verderber diantaranya adalah kesan terhadap diri kita sendiri (self appraisal - viewing self as an object), reaksi serta respon seseorang terhadap diri (reaction and response of others) (Andaryanti \& Indrawati, 2019). Hasil tersebut menunjukkan bahwa secara keseluruhan dimensi aktual diri berada pada kategori sedang dengan nilai rata-rata 65,6. 
Artinya dimensi aktual diri dapat dikatakan responden belum optimal karena masih banyak yang belum menganggap dirinya tergolong baik dan stabil.

Dimensi kedua dari konsep diri adalah ideal self concept. Dimensi ini mengukur bagaimana seseorang ingin melihat dirinya sendiri. Ideal self concept sangat terkait dengan harga diri (self esteem). Self esteem adalah sikap positif seseorang terhadap dirinya sendiri. Pada dimensi ideal self-concept pada kategori setuju menjawab sebanyak $59 \%$ pada pernyataan saya ingin menjadi orang yang bijak dalam mengambil keputusan. Artinya orang tersebut mempunyai harapan yang sesuai dengan kemampuannya (Gamayanti, 2016). Hal ini dapat memperbaiki diri karena seseorang sanggup mengungkapkan aspek-aspek kepribadian yang tidak disukainya dan mengubahnya (Widiarti, 2017). Serta ingin menjadi orang yang baik dalam menjalani hidup yang dimiliki dengan memberikan pengaruh terhadap proses berpikir, perasaan, keinginan, nilai maupun tujuan hidup seseorang sehingga memiliki penyesuaian diri yang lebih baik (Anissa dan Handayani, 2012). Kemudian pada kategori setuju menjawab sebanyak $53 \%$ pada pernyataan saya ingin menjadi orang yang update (modern) seiring kemajuan teknologi. Hal ini sesuai pada zaman modern seperti saat ini, kepraktisan merupakan hal yang sangat penting. Untuk kebutuhan seperti keuangan, teknolgi yang dapat digunakan misalnya berkembangnya e-money (Lintangsari et al., 2018). Hasil tersebut menunjukkan bahwa secara keseluruhan dimensi ideal diri berada pada kategori sedang dengan nilai rata-rata 74,7. Artinya dimensi ideal diri dapat dikatakan bahwa responden ingin menjadi seseorang yang bijak dan ideal untuk dirinya sendiri.

Dimensi ketiga dari konsep diri adalah private self concept. Dimensi ini mengukur bagaimana perasaan seseorang, ketika orang lain melihat dirinya sendiri. Bagaimana seseorang melihat dirinya akan sangat memengaruhi private self concept yang dimiliki oleh orang tersebut. Pada dimensi private self concept pada kategori tidak setuju sebanyak $39 \%$ pada pernyataan orang lain mengganggap saya sebagai individu yang kurang update (tradisional) dan pada pernyataan orang lain mengganggap saya sebagai individu yang akan melakukan apa saja untuk membeli barang yang saya idamkan. Kedua pernyataan tersebut terjadi karena konsep diri negatif akan meyakini dan memandang bahwa dirinya lemah, tidak berdaya, tidak dapat berbuat apa- apa, tidak kompeten, gagal, malang, tidak menarik, tidak disukai dan kehilangan daya tarik terhadap hidup begitupun sebaliknya (Anissa dan Handayani, 2012). Permainan peran yang merupakan awal dari pengembangan konsep diri bagaimana cara oranglain memandang diri kita (roles you play-role taking), dan kelompok rujukan yang menunjukkan bahwa kita merupakan bagian di dalamnya, semakin kelompok rujukan yang menganggap diri kita positif maka konsep diri semakin positif (reference groups) (Andaryanti \& Indrawati, 2019). Hasil tersebut menunjukkan bahwa secara keseluruhan dimensi diri sosial berada pada kategori sedang dengan nilai rata-rata 65,0. Artinya dimensi diri sosial dapat dikatakan bahwa responden di dalam lingkungan terlihat memainkan peran yang bagaimana orang lain melihat dirinya tergolong ke dalam hal positif atau negatif.

Dimensi ketiga dari konsep diri adalah social self concept. Dimensi ini mengukur bagaimana seseorang ingin orang lain melihat dirinya sendiri. Menyatakan pandangan masyarakat atau orang lain bagaimana persepsi masyarakat atau orang lain terhadap diri seseorang sangat memengaruhi konsep diri. Pada dimensi social self concept pada kategori setuju sebanyak $57 \%$ pada pernyataan saya ingin orang lain melihat saya sebagai individu yang baik dalam berperilaku. Hal tersebut dikarenakan individu ingin dirinya terlihat sebagai individu yang baik dalam berperilaku dan yakin akan standar-standar dan pengatahuan terhadap dirinya tanpa terpaku pada pendapat orang lain (Gamayanti, 2016). Hasil tersebut menunjukkan bahwa secara keseluruhan dimensi sosial ideal berada pada kategori sedang dengan nilai rata-rata 77,2. Artinya dimensi sosial ideal dapat dikatakan bahwa responden ingin dilihat oleh orang lain dalam lingkungan menjadi seseorang yang baik untuk dirinya dan orang lain.

Konsep diri pada ibu rumah tangga dalam penelitian ini mempunyai nilai rata-rata 70,1 (Tabel 2). Pada dimensi aktual diri berada pada kategori sedang dengan nilai rata-rata 65,6. Artinya dimensi aktual diri dapat dikatakan belum optimal karena masih banyak yang belum 
menganggap dirinya tergolong baik dan stabil. Pada dimensi diri ideal berada pada kategori sedang dengan nilai rata-rata 74,7. Artinya dimensi ideal diri dapat dikatakan bahwa responden ingin menjadi seseorang yang bijak dan ideal untuk dirinya sendiri. Pada dimensi diri sosial berada pada kategori sedang dengan nilai rata-rata 65,0. Artinya dimensi diri sosial dapat dikatakan bahwa responden di dalam lingkungan terlihat memainkan peran yang bagaimana orang lain melihat dirinya tergolong ke dalam hal positif atau negatif. Pada dimensi diri sosial ideal berada pada kategori sedang dengan nilai rata-rata 77,2. Artinya dimensi sosial ideal dapat dikatakan bahwa responden ingin dilihat oleh orang lain dalam lingkungan menjadi seseorang yang baik untuk dirinya dan orang lain.

Tabel 2 Dimensi Variabel Konsep Diri

\begin{tabular}{lccr}
\hline \multicolumn{1}{c}{ Dimensi } & Nilai Min-Mak & $\begin{array}{c}\text { Rata-rata } \pm \text { Standar } \\
\text { Deviasi }\end{array}$ & Kategori \\
\hline Aktual Diri & $29-98$ & $65,6 \pm 13,8$ & Sedang \\
Diri Ideal & $60-96$ & $74,7 \pm 7,5$ & Sedang \\
Diri Sosial & $37-96$ & $65,0 \pm 14,6$ & Sedang \\
Diri Sosial Ideal & $60-93$ & $77,2 \pm 7,3$ & Sedang \\
\hline Konsep Diri & $54-95$ & $70,1 \pm 9,6$ & Sedang \\
\hline
\end{tabular}

\section{Pengaruh Konsep Diri terhadap Impulse Buying}

Hasil analisis uji regresi sederhana dapat diketahui hasil kolerasi antara konsep diri dan impulse buying $(\mathrm{R}$ square $)=0,447$. Artinya dapat diketahui bahwa penelitian ini menjelaskan pengaruh konsep diri terhadap impulse buying pada ibu rumah tangga sebesar $44,7 \%$. Sementara sisanya $55,3 \%$ dipengaruhi oleh variabel lain yang tidak diteliti. Hasil analisis juga menunjukkan bahwa konsep diri pada ibu rumah tangga berpengaruh negatif dan signifikan terhadap impulse buying $(\beta=-0,156, p=0,000)$.

Tabel 3 Hasil Uji Pengaruh Konsep Diri terhadap Impulse Buying

\begin{tabular}{lccc}
\hline \multicolumn{1}{c}{ Variabel } & Nilai Min-Mak & Impulse Buying & Kategori \\
& B & & Sig. \\
\hline Konstanta & 59,103 & - & 0,000 \\
Konsep Diri & $-0,669$ & $-0,156$ & 0,000 \\
\hline F & & & 79,248 \\
Sig. & & & 0,000 \\
R & & & 0,669 \\
R Square & & 0,447 \\
Adjusted R Square & & 0,441 \\
\hline
\end{tabular}

\section{Pembahasan}

Salah satu tantangan yang dihadapi oleh ibu rumah tangga adalah impulse buying. Impulse buying merupakan perilaku konsumen yang ditandai dengan adanya pembelian secara spontan yang dapat menghasilkan keputusan yang cepat dalam memutuskan sesuatu tanpa pertimbangan yang matang serta cenderung berulang dan tindakan tersebut dianggap wajar. Pembelian impulsif dapat juga diartikan sebagai suatu fenomena yang sedang melanda kehidupan masyarakat terutama yang tinggal di perkotaan (Sihotang, 2009). Ibu rumah tangga berperan penting dalam ekonomi keluarga (Hanum, 2017) yang artinya ibu rumah tangga tidak seharusnya terjebak dengan impulse buying.

Perilaku impulse buying muncul karena adanya dorongan secara spontan. Motivasi dapat digambarkan sebagai tenaga pendorong dalam diri yang memaksa individu untuk bertindak. Tenaga pendorong dapat dihasilkan oleh keadaan tertekan yang timbul sebagai akibat dari kebutuhan yang tidak terpenuhi. Menurut Utami (2010) motivasi untuk berbelanja 
yang dilakukan oleh konsumen antara lain adalah untuk menghilangkan kesepian, menghilangkan kebosanan, menganggap berbelanja sebagai olahraga, memburu penawaran terbaik, memenuhi fantasi, dan menekan depresi. Menurut Utami (2010) pada perilaku pembelian dengan motivasi hedonis, konsumen menganggap berbelanja sebagai suatu kegairahan, kepuasan dan kesenangan panca indera.

Pada rentang waktu singkat, perilaku impulse buying menciptakan perasaan yang penuh kegembiraan untuk bersenang-senang dan pemenuhan kebutuhan dalam jangka pendek (Baumeister, 2002). Salah satu dimensi dari impulse buying adalah hedonik. Sudiantara (2003) mengatakan bahwa hedonisme adalah suatu paham atau aliran yang memiliki anggapan bahwa hanya ada satu hal yang paling baik bagi manusia, yaitu kesenangan atau kenikmatan. Pandangan tersebut sangat berpengaruh pada kehidupannya, sehingga orang akan bertindak sedemikian rupa sampai akhirnya mencapai jumlah kenikmatan yang besar atau banyak (Rianton, 2013). Konsumen yang mengalami konflik psikologis akan berjuang mempertimbangkan antara mendahulukan kepuasan diri atau mempertimbangkan konsekuensi jangka panjang dari pembelian. Konsumen seringkali mengurangi evaluasi pengetahuan tentang produk, sehingga konsumen membeli secara spontan tanpa mempertimbangkan konsekuensi di masa mendatang.

Berdasarkan hasil penelitian, impulse buying pada ibu rumah tangga termasuk ke dalam kategori sedang dengan nilai rata-rata sebesar 65,8 , terlihat dari dimensi hedonik memiliki rata-rata tertinggi sebesar 68,0 dan rata-rata terendah pada dimensi perencanaan sebesar 63,5. Hal ini menjelaskan bahwa ibu rumah tangga masih belum optimal dalam menjaga diri dari perilaku impulse buying. Ibu rumah tangga sebagai konsumen dalam memenuhi kebutuhan keluarga sebaiknya lebih mementingkan kebutuhan keluarga sesuai rencana, tetapi proses otomatisasi perilaku impulse buying dapat terjadi disebabkan adanya stimulasi kuat dari lingkungan yang muncul tanpa dilandasi oleh pertimbangan kebutuhan secara rasional. Motivasi lain yang dapat memengaruhi kegiatan berbelanja yang dilakukan oleh konsumen adalah motivasi hedonis, dimana seseorang akan berbelanja karena merasa mendapatkan kesenangan dan merasa bahwa berbelanja merupakan suatu kegiatan yang menarik (Astiti \& Puri, 2016).

Hasil analisis menunjukkan bahwa impulse buying pada ibu rumah tangga dipengaruhi oleh konsep diri. Perilaku impulse buying pada ibu rumah tangga menurun dengan bertambah baiknya konsep diri pada ibu rumah tangga tersebut. Konsep diri adalah gambaran atas sikap dan perasaan seseorang tentang dirinya yang dipelajari melalui pengalaman pribadi maupun yang berhubungan dengan orang lain yang dapat memengaruhi perilaku dirinya sendiri. Faktor-faktor yang mempengaruhi konsep diri menurut Rakhmat (2015) adalah: a). orang lain; b) kelompok rujukan (reference group). Selanjutnya ada lima petunjuk orang yang memiliki konsep diri positif yaitu, memiliki keyakinan untuk menyelesaikan masalah, merasa setara dengan orang lain, menerima pujian dari orang lain tanpa rasa malu, memiliki kesadaran bahwa setiap orang mempunyai berbagai perasaan, keinginan dan perilaku yang tidak seluruhnya disetujui oleh masyarakat serta mampu memperbaiki diri karena sanggup mengungkapkan aspek-aspek kepribadian yang tidak disukainya dan mengubahnya, serta memiliki keyakinan untuk menyelesaikan masalah.

Berdasarkan hasil penelitian yang telah dilakukan variabel konsep diri pada ibu rumah tangga termasuk ke dalam kategori sedang dengan rata-rata $70,1 \%$, terlihat dari dimensi sosial self concept memiliki rata-rata tertinggi sebesar $77,2 \%$ dan dimensi private self concept memiliki rata-rata terendah sebesar $65,0 \%$. Hal ini menjelaskan bahwa konsep diri adalah konsep dasar tentang diri sendiri, pikiran dan opini pribadi, kesadaran tentang apa dan siapa dirinya, dan bagaimana perbandingan antara dirinya dengan orang lain serta bagaimana beberapa idealisme yang telah dikembangkannya. Konsep diri sangat erat kaitannya dengan diri individu. Kehidupan yang sehat, baik fisik maupun psikologi salah satunya didukung oleh konsep diri yang baik dan stabil. Konsep diri individu akan membimbing dirinya menuju aktifitas dalam masyarakat. Konsep diri inilah yang akan memberikan pengaruh terhadap gaya maupun pola tingkah laku individu (Mukhlishi, 2016). Konsep diri yang positif dapat membantu 
seseorang untuk meningkatkan kepercayaan terhadap dirinya sehingga dapat memotivasi seseorang untuk dapat menjadi lebih baik lagi (Novilita and Suharnan, 2013). Oleh karena itu, konsep diri positif perlu dikembangkan dan menjadi control untuk menurunkan kecenderungan untuk melakukan perilaku yang negatif termasuk juga impulse buying.

\section{SIMPULAN DAN SARAN}

Hasil penelitian menunjukkan bahwa konsep diri dan impulse buying pada ibu rumah tangga termasuk dalam kategori sedang. Konsep diri berpengaruh negatif dan signifikan terhadap impulse buying. Hasil analisis ini mengindikasikan bahwa konsep diri yang semakin baik dapat menurunkan impulse buying pada ibu rumah tangga. Artinya, impulse buying pada ibu rumah tangga dapat dikontrol oleh konsep diri ibu rumah tangga tersebut. Dengan demikian, cara yang dapat dilakukan untuk mengurangi impulse buying pada ibu rumah tangga adalah dengan cara meningkatkan konsep diri pada ibu rumah tangga.

\section{DAFTAR PUSTAKA}

Andaryanti, B. C., \& Indrawati, E. S. (2019). Hubungan Antara Konsep Diri Dengan Perilaku Konsumtif Terhadap Pakaian Pada Siswi Kelas XI SMAN 1 Pati. Empati, 7(4), 60-66.

Anissa, N., \& Handayani, A. (2012). Hubungan Antara Konsep Diri dan Kematangan Emosi dengan Penyesuaian Diri Istri Yang Tinggal Bersama Keluarga Suami. Jurnal Psikologi Pitutur, 1(1), 56-64.

Aprilia, E. D., \& Mahfudzi, R. (2020). Gaya Hidup Hedonisme dan Impulse Buying pada Mahasiswa. Jurnal Ecopsy, 7(2), 71-78. https://doi.org/10.20527/ecopsy.v7i2.7390

Astiti, I. A. T. R. \& Puri, D. (2016). Pengaruh Motivasi Hedonis dan Atmosfer Toko Terhadap Pembelian Impulsif pada Remaja Putri di Denpasar. Jurnal Psikologi Udayana, 3(2), 209-19.

Baumeister, R. F. (2002). Yielding to temptation: Self control failure, impulsive purchasing, and customer behavior. Journal of Consumer Research, 28, 670-676. DOI: 10.1086/338209

Bressolles, G., Durrieu, F., \& Giraud, M. (2007). The impact of electronic service quality's dimention on customer satisfaction and buying impulse. Journal of Customer Behaviour, 6(1), 37-56. http://doi.org/10.1362/147539207X198365

Chrisnawati, D., \& Abdullah, S. M. (2011). Faktor-Faktor Yang Memengaruhi Perilaku Konsumtif Remaja Terhadap Pakaian (Studi Kasus Pada Remaja Berstatus Sosial Ekonomi Rendah). Jurnal Spirits, 2(1), 1-14.

Gamayanti, W. (2016). Gambaran Penerimaan Diri (Self-Acceptance) pada Orang yang Mengalami Skizofrenia. Psympathic: Jurnal IImiah Psikologi, 3(1), 139-152. https://doi.org/10.15575/psy.v3i1.1100

Hanum, S. L. (2017). Peran Ibu Rumah Tangga dalam Membangun Kesejahteraan Keluarga. Journal of Multidisciplinary Studies, 5(2), 1-9.

Kusnawan, A., Silaswara, D., Andy, \& Sefung, T. (2019). Pengaruh Diskon pada Aplikasi eWallet terhadap Pertumbuhan Minat Pembelian Impulsif Konsumen Milenial di Wilayah Tangerang. Jurnal Sains Manajemen, 5(2), 137-160.

Lintangsari, N. N., Hidayati, N., Purnamasari, Y., Carolina, H., \& Ramadhan, W. F. (2018). Analisis Pengaruh Instrumen Pembayaran Non-Tunai Terhadap Stabilitas Sistem Keuangan Di Indonesia. Jurnal Dinamika Ekonomi Pembangunan, 1(1), 47. https://doi.org/10.14710/jdep.1.1.47-62

Maula, Z., \& Kustanti, E. R. (2020). Hubungan Antara Psychological Well-Being Dengankecenderungan Perilaku Konsumtif Pada Siswa Pengguna Go-Pay Yang 
Menggunakan Promo Cashback di SMA Negeri 2 Semarang. Empati, 8(3), 7-14.

Muflih, F. (2018). Analisis Pengaruh Faktor Situasional Terhadap Pembelian Impulsif Pada Binjai Supermall. At-Tawassuth: Jurnal Ekonomi Islam, 3(2), 99-117.

Mukhlishi. (2016). Konsep Diri Dalam Berinteraksi Sosial Remaja Gapura Kabupaten Sumenep. Kabilah: Journal of Social Community, 1(1), 53-71.

Novilita, H., \& Suharnan. (2013). Konsep Diri Adversity Quotient Dan Kemandirian Belajar Siswa. Jurnal Psikologi Tabularasa, 8(1), 619-32.

Nurhaini, D. (2018). Pengaruh Konsep Diri Dan Kontrol Diri Dengan Perilaku Konsumtif Terhadap Gadget Remaja SMAN 1 Tanah Grogot, 6(1), 211-223.

Oke, A. O., Kamolshotiros, P., \& Popoola, O. Y. (2016). Consumer Behavior towards Decision Making and Loyalty to Particular Brands. 6(2007), 43-52.

Oktivera, E., Wirawan, M. (2020). E- Sales Promotion Membentuk Impulse Buying Konsumen Studi Kasus: Digital Payment OVO. 7(1), 1-7.

Pangkaca, Nilam, Asri Rejeki, and Ima Fitri Sholichah. 2020. "Pengaruh Kontrol Diri Terhadap Pembelian Impulsif Belanja Online Pada Karyawan Departement Store." Jurnal Indonesia Sosial Sains 1 (September): 132-41.

Parboteeah, D. V., Wells, J. D., \& Valacich, J. S. (2009). The Influence of Website Characteristics on a consumer's Urge to buy impulsively. Information Systems Research, 20(1), 60-78.

Pradana, A. A., \& Wahyuningdyah, R. Y. (2019). Analisis Pengaruh Potongan Harga, Paket Bonus, Pajangan dalam Toko dan Suasana Toko Terhadap Perilaku Pembelian Impulsif Pada Pelanggan Minimarket Indomaret Hybrid di Kota Semarang. Jemap, 2(1), 47. https://doi.org/10.24167/jemap.v2i1.2099

Pradana, E., \& Suparna, G. (2016). Pengaruh Store Environment Dan Impulse Buying Tendency Terhadap Urge To Buy Impulsively Dan Impulse Buying Behaviour. E-Jurnal Manajemen Universitas Udayana, 5(7), 255200.

Pramesty, D. W., \& Simanjuntak, M. (2020). Konsep diri, gaya hidup, strategi pemasaran, dan pembelian impulsif antargenerasi. Jurnal IImu Keluarga dan Konsumen, 13(1), 87-98.

Ramadhan, A. F., \& Simanjuntak, M. (2018). Perilaku Pembelian Hedonis Generasi Z: Promosi Pemasaran, Kelompok Acuan, dan Konsep Diri. Jurnal Ilmu Keluarga Dan Konsumen, 11(3), 243-254. https://doi.org/10.24156/jikk.2018.11.3.243

Ramadhani, Z. N. F., Oktora, S. I. (2019). Determinan Transaksi Nontunai Di Indonesia Dengan Pendekatan Error Correction Mechanism (Ecm) Model. Indonesian Journal of Statistics and Its Applications, 3(1), 62-77. https://doi.org/10.29244/ijsa.v3i1.190

Rianton, (2013). Hubungan antara konformitas kelompok teman sebaya dengan gaya hidup hedonis pada mahasiswa kab. Dhamasraya di Yogyakarta. Jurnal Publikasi Universitas Ahmad Dahlan, 2, (1), 1-15.

Sari, D. E., Handoko, R., \& Rochim, A. I. (2018). Pengaruh Online Shop Jejaring Sosial Terhadap Perilaku Konsumtif Pada Ibu Rumah Tangga Kabupaten Mojokerto (Studi Kasus Ibu Rumah Tangga Di Desa Mojotamping, Kecamatan Bangsal, Kabupaten Mojokerto). Representamen, 4(01). https://doi.org/10.30996/representamen.v4i01.1423

Sari, Siwi Indra, Wahyuningsih Safitri, and Ratih Dwilestari Puji Utami. 2018. "Pengaruh Pendidikan Kesehatan Dengan Metode Demonstrasi Terhadap Praktik Pertolongan Pertama Luka Bakar Pada Ibu Rumah Tangga Di Garen Rt.01/Rw.04 Pandean Ngemplak Boyolali." Jurnal Kesehatan Kusuma Husada, 98-105. https://doi.org/10.34035/jk.v9i1.266.

Shingh, S. (2019). An exploration of e-impulse buying. 10(1). 
Toth, M. (2014). The Role of Self-Concept in Consumer Behavior" (2014). UNLV Theses, Dissertations, Professional Papers, and Capstones. 2161. http://dx.doi.org/10.34917/6407916

Uygur, E. M. (2018). Consumer Impulsive Buying Tendency Scale Development Using Mixed Methodology. Beykoz Akademi Dergisi, 6(2), 125-141. https://doi.org/10.14514/byk.m.26515393.2018.6/2.125-141

Utami, C. W. (2010). Manajemen Ritel. Edisi 2. Jakarta: Salemba Empat.

Widiarti, P. W. (2017). Konsep Diri (Self Concept) Dan Komunikasi Interpersonal Dalam Pendampingan Pada Siswa SMP Se Kota Yogyakarta. Informasi, 47(1), 135. https://doi.org/10.21831/informasi.v47i1.15035 